\title{
NEDERLAND'S BUITENLANSCHE HANDEL EN DE VEREENIGING HET BUITENLAND.
}

In het jongste rapport van den secretaris der Britsche legatie to Buenos-Ayros (Diplomatic and Consular Reports 1889 No. 573) leest men $\mathrm{o} . \mathrm{m}$. het volgende:

nVerschillende onzer voornaamste on beste uitvocr-artikelen worden hier nooit gezien, maar in plaats daarvan worden hier namaaksels van veel mindere $\mathrm{kwaliteit}$ ingevoerd. Dit brengt mij op een der zwakke punten van onze handelsverbindingen met de Argentijnsche republiek. Ik bedoel de zeer dikwijls voorlkomende aanstelling van agenten voor Engelsche handelshuizen, alleen maar omdat die personen een lage commissie berekenen, en zonder dat er op gelet wordt of bij hen de ware ijver wordt gevonden ter bevordering van den handel met Engeland. Zulke agenten, dio gewoonlijk zelven geen Engelschen zijn, zijn veelal geneigd de belangen hunuer eigen natie meer te bevorderen dan die van Engeland, en het gevolg is dat een tak van handel voor ons verloren gaat, die, indien daarvoor de noodige zorg ware gedragen, integendeel tot groote ontwikkeling had kunnen geraken.

"Het redmiddel in deze moet bestaan in de vestiging hier to lande van een grooter aantal Engelsche handelshuizen, die hun eigen landslieden gebruiken als reizigers in het binnenland om aldaar de behoeften der bevolking te leeren kennen. Zulke huizen zouden zeker langzamerhand een belangrijk aandeel verkrijgen in den handel met het binnenland, die tegenwoordig hoofdzakelijk in handen is van onze buitenlandsche concurrenten. Onze fabrikanten in Engeland zouden dan vernemen, wat zij te doen hebben om hunne fabrikaten naar de behoeften on den smaak der inwoners van Argentinie in te richten, en onze invoeren zouden dientengevolge een aanzienlijke vermeerdering kunnen ondergaan."

Ten andere wordt aan het verslag over 1888 van onzen ijverigen Nederlandschen consul te Buenos-Ayros, den heer L. val Riet, (Consulaire verslagen $1889 \mathrm{~N}$. 132) dit ontleend: 
"Ten slotte vinde nog dn volgende opmerking eene plaats. Wordt hier to voren de oprichting van verdere Nederlandsche firma's in overweging gegeven, daarbij bestaat niet de bedoeling het vermoeden op te wekken, aslof de uitoefening van het handelsverkeer in Argentinie gemakkelijk ware. Het tegendeel is bet geval en hoezeer dit waar is, blijkt uit het feit, dat eene firma te Buenos-Ayros, alvorens zich te vestigen, hare zaken gedurende den tijd van een jaar door een reeds bestaand huis liet loopen en daarvoor eene commissie betaalde van $f 20.000$. Aan hen, die eene zaak in Argentinie willen beginnen, moet derhalve de zeer ernstige raad worden gegeven, handel, personen en toestanden aldaar nauwkeurig na te gaan, voor zij hunne kantoren openen."

Terwijl de wenken, die hier door twee alleszins bevoegde autoriteiten worden gegeven, in het algemeen alle aandacht verdienen, zij het den inzender dezer beide aanhalingen geoorloofd or tevens op te wijzen, hoezeer ze te zamen gevoegd eene volledige goedkeuring bevatten van het pogramma der vereeniging Het Buitenland.

Immers het doel dezer vereeniging is geen ander dan voor Nederland te weeg te brengen hetgeen door den Engelschen verslaggever aan zijn landslieden wordt aanbevolen als het juiste middel om den Engelschen uitvoerhandel tot nieuwe ontwikkeling te brengen. En zij tracht dit doel te bereiken door de verplaatsing naar den vreemde van Nederlandsche jongemannen aanvankelijk in ondergeschikte handelsbetrekking, opdat deze eerst in een goede leerschool de plaatselijke kennis mogen opdoen, die, naar de heer van Riet ook weder schrijft, onmisbaar is ten einde daar werkelijk nuttig werkzaam te zijn.
Amsterdam, Juli 1889.
G. M. B. 